\title{
Problematic on the use of synthetic pesticides against insect pests of tomato, (Lycopersicon esculentum Mill.) in Foumbot, Western Region of Cameroon
}

\author{
Dzokou Victor Joly ${ }^{1 *}$, Yana Wenceslas ${ }^{2}$, Asafor Henry Chotangui ${ }^{1}$, Mouyiche Mbouemboue \\ Ange Nathanaël ${ }^{1}$ and Tamesse Joseph Lebel $^{3}$
}

\author{
${ }^{1}$ Department of Crop Sciences, Faculty of Agronomy and Agricultural Sciences, Crop Protection, UR_PHYZA \\ (Laboratory of Agricultural Zoology), University of Dschang, P.O. Box 222 Dschang, Cameroon \\ ${ }^{2}$ Laboratory of Biological Sciences, Faculty of Sciences, University of Bamenda, P.O. Box 39 Bambili, Cameroon \\ ${ }^{3}$ Laboratory of Zoology, Higher Teachers' Training College, University of Yaounde I, P.O. Box 47 Yaounde, \\ Cameroon
}

*Corresponding Author: dzovijo@yahoo.fr, victor.dzokou@univ-dschang.org

\begin{abstract}
An inventory of pest insect of tomato (Lycopersicon esculentum) was carried out in 2018 in five localities of Foumbot production area to find out the effects of using synthetic insecticides on the worrying insects. The quantity applied and frequency of application was equally assessed and compared to those prescribed by the producers. Caiman B, Cypercal, Parastar, Cybemex and Plusfort are used. The insects were captured weekly during March and February during fruits formation and when they are getting ripe. The results showed that the doses and the frequencies of applications are different from a producer to the other. A total of 6485 insect pests belonging to the order Diptera, Hemiptera and Lepidoptera were captured. The greatest number of insect pests was captured in the locality of Mangoum 1 (19.75\%). Bemisia tabaci (Hemiptera: Aleyrodidae) was the most abundant species (62.94\%). The damages bring a setback in quantity and quality of the harvest, fruits are not good any more for consumption. The usage of these pesticides without respecting the norms has not reduced the population of the insect pests of tomato at Foumbot, showing that the insects became resistant. We suggest a strict respect of the doses and frequencies and the use of bio-pesticides and essential oils, respectful of the environment.
\end{abstract}

Keywords: Lycopersicon esculentum, Pesticides, Doses, Insect pests, Inventory, Cameroon.

\section{INTRODUCTION}

Market gardening is one of the main activities for a great part of the population in Foumbot (Kengne \& De Jong, 2002). Tomato cultivation suffers from damages caused by insect pests, fungal, bacterial and viral diseases. Insect pests affecting tomato production include the Hemiptera, Lepidoptera and the Diptera. Germain et al. (2009) for the first time indicated the presence of Tuta absoluta Meyrick (Lepidoptera: Gelechiidae) on tomato in France. The authors mentioned that the main host of Tuta absoluta is the tomato in which it develops at the expense of all the surrounding parts. This pest was initially reported in eastern Spain in late 2006 (Urbaneja et al., 2007), and has subsequently spread throughout the Mediterranean Basin and Europe. Some of these insects transmit toxic saliva to plants causing the yellowing of the plant parts. The feeding process is a means of transmission of viruses, fungi and bacteria from one plant to another. Intensive cultivation of tomato has led to the development of a diversified fauna of pests whose damages are harmful to crops affecting yield (Novotny \& Basset, 2005).

According to Markham et al. (1994), Bemisia tabaci Gennadius (Hemiptera-Aleyrodidae) is the vector of over 60 plant viruses in the genera Geminivirus, Clostervirus, Nepovirus, Carlavirus, Potyvirus and rod-shaped DNA virus. Hitherto, the main effective means used to control these pests by Cameroonian farmers is the use of chemical products. Application of these products may lead to environmental pollution, accumulation of chemical residues on crops, development of resistance and others (Edwards-Jones, 2008). To solve the problem of little or poor information on tomato pests in the tropical zone, researchers have undertaken various studies including inventories of entomofauna in market gardening (Djiéto-Lordon \& Aléné, 2002; Djiéto-Lordon et al., 2014; Mokam et al., 2014). According to Fontem et al. (1999), studies carried out in the West region of Cameroon (Foumbot and Dschang) indicated that tomatoes were seriously affected by different insect pests: Dacus curcubitae Coq (Diptera-Trypetidae), Helicoverpa armigera Hub (Lepidoptera-Noctuidae), and Bemisia tabaci Sulzer Genn. More recent studies carried out at Koutaba and Okola showed that Dacus punctatifrons Krash and Helicoverpa armigera are the most important insect pests in 
these localities causing yield drop varying between 33.4 to $49.76 \%$ (Heumou et al., 2015). Despite their predominant agronomic and economic importance in market gardening in Cameroon, very little is known about insect pests of tomatoes and chemical management against these pests by the tomato producers with very few data available. Hence, this study aimed to provide basic data on insect pests of tomatoes and pest management (use and efficiency) by the producers.

\section{MATERIALS AND METHODS}

Data collection was conducted during the months of February and March 2018 in 5 villages in the Foumbot subdivision $\left(05^{\circ} 30^{\prime} \mathrm{N}, 010^{\circ} 37^{\prime} \mathrm{E}\right.$; altitude: $\left.1000 \mathrm{~m}\right)$ in the Western Highlands (Fig. 1). It's situated in a vast plain, slightly inclined towards the west. The soils are volcanic and the relief is made of small high hills. The climate is the tropical humid mountain type, with two seasons; a rainy season that runs from March to November and a short dry season that runs from November to March. The Noun River marks the main boundary in the west of the region and is the main hydrographic source. Other little streams also exist in addition to the river Nkoup which longitudinally crosses a good part of the region.

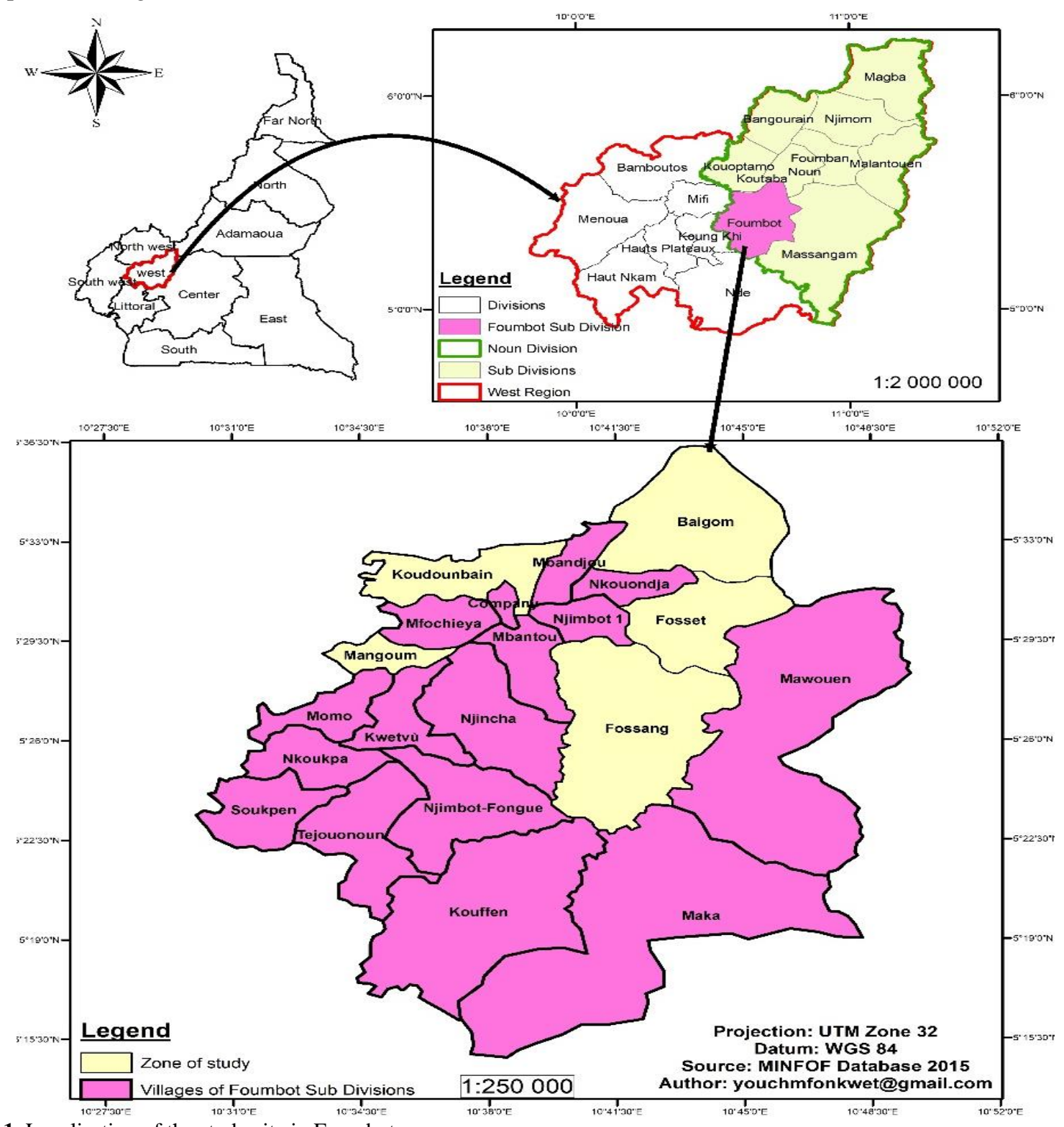

Figure 1. Localisation of the study site in Foumbot.

The 5 villages were chosen following the cardinal points. In the north, we had Baigom where one farm was sampled, in the south, we had Mangoum, with two farms sampled, two villages were taken in the west, that is Fossang and Fosset where one farm was sampled each. Finally, Nkoudounbain was chosen in the east and two farms were sampled. Hence a total of five villages and seven farms were implicated in the study.

The plant material used in this study is the tomato plant. Various tomato varieties are cultivated by Foumbot farmers, with the must cultivated variety being the "RIO GRANDE" variety. The characteristics of this variety 
cultivated here are high post-harvest conservation duration, quite large fruit, with a thick epidermis which is resistant to shock. The tomato balks are strewn with cabbage line.

Insects were captured with the help of an entomological net of $0.5 \mathrm{~mm}$ mesh size and a mouth aspirator. Host plants were visually searched at random. These insects were preserved in $70 \%$ ethanol. The collection was kept in the Laboratory of Agricultural Zoology, University of Dschang (LAZUDs). Insects were identified according to their morphological characteristics under the stereomicroscope using available regional keys (Delvare \& Aberlenc, 1989; White \& Elson-Harris, 1994; Daly et al., 1998; Ramel, 2010).

\section{RESULTS AND DISCUSSION}

Generally, during the study, a total of 6485 insect pests were collected and identified to belong to three orders; Diptera (1362 individuals, 21\%), Hemiptera (4082 individuals, 62.94\%) and Lepidoptera (1041 individuals, 16.05\%). Three species belong to the order Diptera: Drosophila melanogaster Meigen (Diptera: Drosophilidae) (vineyard fruit fly), Drosophila hydei Sturtevant (Diptera: Drosophilidae) (black fruit fly); Drosophila sp. (Diptera: Drosophilidae); two species to the order Lepidoptera: Tuta absoluta (Lepidoptera: Gelechiidae), (tomato leaf miner), Tuta sp. (Lepidoptera: Gelechiidae), and one species to the order Hemiptera: Bemisia tabaci (Hemiptera: Aleyrodidae), (whitefly) (Table 1). This is in accordance with the work of Heumou et al. (2015) and Fontem et al. (1999), who cited the presence of these orders as insect pests of tomato in the localities of Okola and Koutaba, and Foumbot and Dschang respectively. Other insect pests captured were very few in number thus, not considered as pests of economic importance.

Table 1. Rate of insects collected per species and per locality

\begin{tabular}{|c|c|c|c|c|c|c|c|c|}
\hline \multirow[b]{2}{*}{ Localities } & \multicolumn{7}{|c|}{ Various collected insects species } & \multirow[b]{2}{*}{ Rate } \\
\hline & $\begin{array}{r}\text { Drosophila } \\
\text { melanogaster }\end{array}$ & $\begin{array}{r}\text { Drosophila } \\
\text { hydei }\end{array}$ & $\begin{array}{r}\text { Drosophila } \\
\text { sp. }\end{array}$ & $\begin{array}{r}\text { Tuta } \\
\text { absoluta }\end{array}$ & $\begin{array}{c}\text { Tuta } \\
\text { sp. }\end{array}$ & $\begin{array}{r}\text { Bemisia } \\
\text { tabaci }\end{array}$ & $\begin{array}{r}\text { Total by } \\
\text { locality }\end{array}$ & \\
\hline Baigom & 78 & 54 & 00 & 71 & 51 & 386 & 640 & $9.87 \%$ \\
\hline Fossang & 136 & 128 & 03 & 101 & 42 & 705 & 1115 & $17.19 \%$ \\
\hline Fosset & 100 & 85 & 00 & 74 & 50 & 441 & 750 & $11.56 \%$ \\
\hline Mangoum 1 & 109 & 108 & 05 & 132 & 59 & 868 & 1281 & $19.75 \%$ \\
\hline Mangoum 2 & 131 & 145 & 06 & 83 & 70 & 681 & 1116 & $17.21 \%$ \\
\hline Nkoudoundain 1 & 80 & 76 & 02 & 89 & 61 & 446 & 754 & $11.63 \%$ \\
\hline Nkoudoundain 2 & 67 & 49 & 00 & 104 & 54 & 555 & 829 & $12.78 \%$ \\
\hline Total by species & 701 & 645 & 16 & 654 & 387 & 4082 & 6485 & $99.99 \%$ \\
\hline Rate & $10.81 \%$ & $9.94 \%$ & $0.25 \%$ & $10.08 \%$ & $5.97 \%$ & $62.94 \%$ & $99.99 \%$ & \\
\hline
\end{tabular}

The different insect pest species were found in all the 5 villages (Table 1), except Drosophila sp. which was absent in Baigom, Fosset and Nkoudounbain. The most frequent insect pest, was Bemisia tabaci present in all the localities. Bemisia tabaci was also the most abundant [Baigom (386 insects, 9.45\%), Fossang (705 insects, 17.27\%), Fossett (441 insects, 10.80\%), Mangoum 1 and 2 (868 insects, 21.26\%) Mangoum 2 (681 insects, 16.68\%), Nkoudoumbain 1 (446 insects, 10.93\%) and Nkoudoumbain 2 (555 insects, 13.60\%)].

In Baigom village, after Bemisia tabaci (386 individuals), the most abundant species were Drosophila melanogaster (78 individuals), Tuta absoluta (71 individuals), Drosophila hydei (54 individuals) and Tuta sp. (51 individuals). In Fossang village, the most abundant species after Bemisia tabaci (705 individuals) are Drosophila melanogaster (136 individuals), Drosophila hydei (128 individuals), Tata absoluta (101 individuals), Tuta sp. (42 individuals) and Drosophila sp. (3 individuals).

In Fossett village, Bemisia tabaci (441 individuals) is followed by Drosophila melanogaster (100 individuals), Drosophila hydei (85 individuals), Tuta absoluta (74 individuals) and Tuta sp. (50 individuals). In Mangoum 1 village, the most abundant species after Bemisia tabaci (868 individuals) are; Tuta absoluta (132 individuals), Drosophila melanogaster (109 individuals), Drosophila hydei (108 individuals), Tuta sp. (59 individuals) and Drosophila sp. (5 individuals). In Mangoum 2 village, hydei (145 individuals), Drosophila melanogaster (131 individuals), Tuta absoluta (83 individuals), Tuta sp. (70 individuals) and Drosophila sp. (6 individuals) closely follow the Bemisia tabaci (681 individuals). In Nkoudounbain 1 village, the most abundant species after Bemisia tabaci (446 individuals) are Tuta absoluta (89 individuals), Drosophila melanogaster (80 individuals), Drosophila hydei (76 individuals), Tuta sp. (61 individuals), and Drosophila sp. (2 individuals). For Nkoudounbain 2 village, we have Tuta absoluta (104 individuals), Drosophila melanogaster (67 individuals), Tuta sp. (54 individuals) and Drosophila hydei (49 individuals).

The species Drosophila melanogaster, Drosophila hydei, Drosophila sp., Tuta absoluta and Tuta sp. were highly represented in the month of March compared to that of February, with the number of individuals of 534, 401, 12, 389 and 217 for March and 167, 244, 4, 265, 170 for the month of February, respectively (Table 2). Contrary to the others, 
Bemicia tabaci is most abundant during the month of February compared to the month of March; with an abundance of 2349 and 1733 individuals, respectively.

Table 2. Rate of insects collected per month

\begin{tabular}{|c|c|c|}
\hline Species & February & March \\
\hline Drosophila melanogaster & 167 & 534 \\
\hline Drosophila hydei & 244 & 401 \\
\hline Drosophila sp. & 04 & 12 \\
\hline Tuta absoluta & 265 & 389 \\
\hline Tuta sp. & 170 & 217 \\
\hline Bemisia tabaci & 2349 & 1733 \\
\hline Total & 3199 & 3286 \\
\hline Rate & $49.33 \%$ & $50.67 \%$ \\
\hline
\end{tabular}

The farmers in these five villages make use of five types of pesticides to control the insect pests of tomato. Four farmers out of seven used "Caïman B" in the villages of Baigom, Nkoudoumbain 1, Mangoum 1 and two farmers at Nkoudoumbain 2 used "Parastar", that of Fossang used "Cypercal +Parastar" while "Cybemex+Plusfort" were used at Fossett (Table 3).

Table 3. History of sampled farms

\begin{tabular}{|c|c|c|c|c|}
\hline \multirow{2}{*}{$\begin{array}{l}\text { Villages and } \\
\text { farms acreage }\end{array}$} & \multirow{2}{*}{$\begin{array}{l}\text { Commercial name of products and } \\
\text { active material }\end{array}$} & \multirow{2}{*}{$\begin{array}{l}\text { Doses and frequencies } \\
\text { recommended }\end{array}$} & \multicolumn{2}{|c|}{$\begin{array}{c}\text { Doses and frequencies of application } \\
\text { use by the producers }\end{array}$} \\
\hline & & & Doses & Frequencies \\
\hline Baigom $700 \mathrm{~m}^{2}$ & $\begin{array}{l}\text { Caïman B (emamectinebenzanoate } 50 \\
\left.\mathrm{~g} \mathrm{~kg}^{-1}\right)\end{array}$ & $\begin{array}{l}240 \mathrm{~g} \text { of product/hectare, } \\
\text { one time for } 14 \text { days }\end{array}$ & One eating spoon & $\begin{array}{l}1 \text { time a } \\
\text { week }\end{array}$ \\
\hline Fossang $600 \mathrm{~m}^{2}$ & $\begin{array}{l}\text { Cypercal } 12 \text { EC (cypermethrine } 100 \mathrm{~g} \\
\mathrm{I}^{1} \text { ) and Parastar } 40 \text { EC (imidaclopride } \\
20 \mathrm{~g} \mathrm{I}^{1}+\text { lambdacyhalothrine } 20 \mathrm{~g} \mathrm{I}^{1} \text { ) }\end{array}$ & $\begin{array}{l}3-41 / \text { hectare or } 120-160 \mathrm{ml} \\
\text { in } 151 \text { of water }\end{array}$ & $\begin{array}{l}\text { A mixture of } 1.51 \text { of } \\
\text { Cypercal with } 1.51 \text { of } \\
\text { Parastar for one hectare }\end{array}$ & $\begin{array}{l}2 \text { times a } \\
\text { week }\end{array}$ \\
\hline Fosset $900 \mathrm{~m}^{2}$ & $\begin{array}{l}\text { Cybemex (cypermethrine } 100 \mathrm{~g} \mathrm{I}^{1} \text { ) and } \\
\text { Plusfort45 SC (chlorpyriphos-ethyl } \\
600 \mathrm{~g} \mathrm{I}^{1} \text { ) }\end{array}$ & $\begin{array}{l}11 / \text { hectare or } 50 \mathrm{ml} \text { in } 151 \\
\text { of water }+45-50 \mathrm{ml} \text { in } 151 \\
\text { of water, } 2 \text { times per season }\end{array}$ & $\begin{array}{l}\text { A mixture of } 1.51 \text { of } \\
\text { Plusfort and } 0.51 \text { Cybemex } \\
\text { for } 24 \text { sprayers of } 151\end{array}$ & $\begin{array}{l}2 \text { times a } \\
\text { week }\end{array}$ \\
\hline $\begin{array}{l}\text { Nkoudounbain } 1 \\
800 \mathrm{~m}^{2}\end{array}$ & $\begin{array}{l}\text { Caïman B (emamectinebenzanoate } 50 \\
\mathrm{~g} \mathrm{~kg}^{-1} \text { ) }\end{array}$ & $\begin{array}{l}240 \mathrm{~g} \text { of product/hectare, } \\
\text { one time for } 14 \text { days }\end{array}$ & $\begin{array}{l}\text { Two eating spoons per } \\
\text { sprayer }\end{array}$ & $\begin{array}{l}3 \text { times a } \\
\text { week }\end{array}$ \\
\hline $\begin{array}{l}\text { Nkoudounbain } 2 \\
750 \mathrm{~m}^{2}\end{array}$ & $\begin{array}{l}\text { Parastar } 40 \text { EC (imidaclopride } 20 \mathrm{gI}^{1} \\
\text { + lambda cyhalothrine } 20 \mathrm{~g} \mathrm{I}^{1} \text { ) }\end{array}$ & $\begin{array}{l}25-50 \mathrm{ml} \text { for } 151 \text { per } \\
\text { hectare, } 2 \text { times per year }\end{array}$ & 1.5l per hectare & $\begin{array}{l}2 \text { times a } \\
\text { week }\end{array}$ \\
\hline $\begin{array}{l}\text { Mangoum } 1 \\
1200 \mathrm{~m}^{2}\end{array}$ & $\begin{array}{l}\text { Caïman B (emamectinebenzanoate } 50 \\
\mathrm{~g} \mathrm{~kg}^{-1} \text { ) }\end{array}$ & $\begin{array}{l}240 \mathrm{~g} \text { of product/hectare, } \\
\text { one time for } 14 \text { days }\end{array}$ & $\begin{array}{l}\text { Two eating spoons per } \\
\text { sprayer }\end{array}$ & $\begin{array}{l}3 \text { times a } \\
\text { week }\end{array}$ \\
\hline $\begin{array}{l}\text { Mangoum } 2 \\
1000 \mathrm{~m}^{2}\end{array}$ & $\begin{array}{l}\text { Caïman B (emamectinebenzanoate } 50 \\
\mathrm{~g} \mathrm{~kg}^{-1} \text { ) }\end{array}$ & $\begin{array}{l}240 \mathrm{~g} \text { of product/hectare, } \\
\text { one time for } 14 \text { days }\end{array}$ & $\begin{array}{l}\text { One and a half eating } \\
\text { spoons per sprayer }\end{array}$ & $\begin{array}{l}3 \text { times a } \\
\text { week }\end{array}$ \\
\hline
\end{tabular}

Despite the various insecticide treatments which vary from one locality to another with various products and doses, the abundance of insect pests did not reduce considerably in the different farms, except in the locality of Baigom (2349 insects, 36.22\% in February and 1733 insects, 26.72\% in March). In this locality, the insecticide used was "Caïman B" at a dose of one eating spoon for a 161 sprayer, at a frequency of once a week. The greatest abundance was obtained in Mangoum 1 (1281 insects), where the farmer curiously used the same insecticide but with a frequency of thrice a week and a dose of two eating spoons for a 161 sprayer. Thus, there is a possibility that the insect pests in the locality of Mangoum 1 have developed a form of resistance due to the excessive use of this chemical product. This is similar to previous findings of Edwards-Jones (2008) who confirmed that excessive use of synthetic products to control insect pests leads to various havocs including resistance. In the various exploitations investigated, the number of insect pests collected varies from one exploitation to the other in spite of the pesticide used and the doses and frequencies of application. Therefore, for every exploitation and depending on the pesticides used, we have: "Caïman B", Baigom (640 insects, 9.87\%), Nkoudounbain 1 (754 insects, 11.63\%), Mangoum 1 (1281 insects, 19.75\%) and Mangoum 2 (1116 insects, 17.21\%); "Parastar", Nkoudounbain 2 (829 insects, 12.78\%); "Cypercal+Parastar", Fossang (1115 insects, 17.19\%); "Cybemex+Plusfort", Fossett (750 insects, 11.56\%). It is difficult in this situation to say which of pesticides used is more efficient and even the dose used.

In February, Bemisia tabaci (Hemiptera: Aleyrodidae) was more abundant compared to the order Diptera and Lepidoptera. During this period, the vegetative growth of the plant was influential and according to Fontem et al. (1999), the Hemiptera species are insect pests of leaves and are abundant on leaves. It should be noted that as the plant goes into maturity, it produces shape and reduce the vegetative cover hence reducing the leaves, this could explain the reduction of the species during the month of March. In March, Diptera and Lepidoptera orders were the most abundant 
in the 5 villages of Foumbot Subdivision. Generally, as the plant gets into maturity, the leaves are shaped and reduced, hence reducing the abundance of leaves so as to permit the fruits to benefit of all nutritive elements.

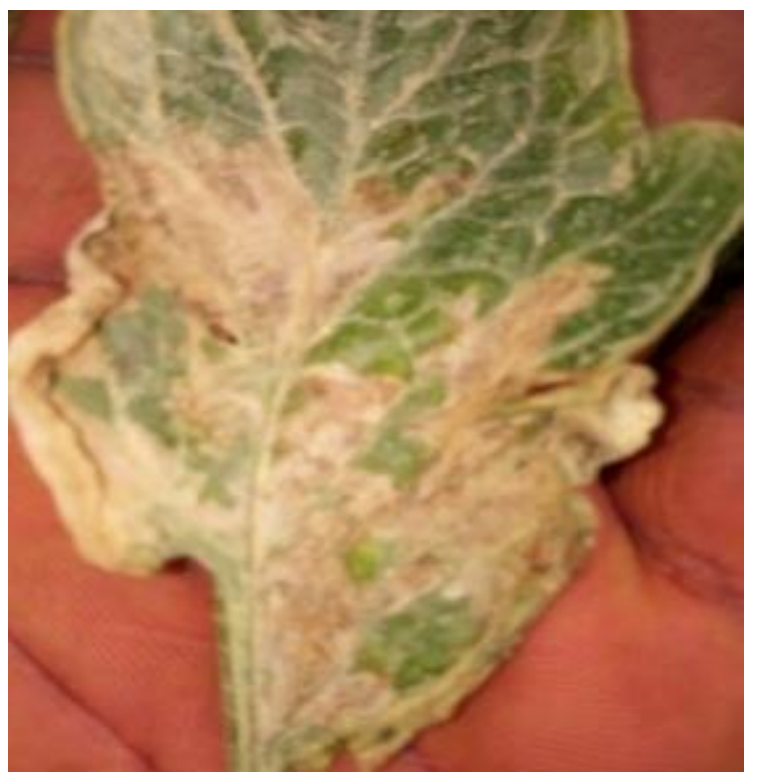

Figure 2. Leaf attacked bythe caterpillars of Lepidoptera.

The leaves coil in a spoon-like shape and yellow leading to stunted growth when severe. This damage is similar to that described by Shankara et al. (2005) who pointed out this as the visible symptoms of the Tomato Yellow Leaf Coil Virus (TYLCV). This disease is transmitted through feeding by the hemipteran species Bemisia tabaci. The irregular galleries on leaves (Fig. 2) which can lead to complete drying and death is in accordance with the damages caused by larvae of the micro- Lepidoptera Tuta absoluta revealed by Ramel (2010). Perforations on the fruits are visible symptoms indicating the presence of larvae of both the order Diptera and Lepidoptera (Fig. 3) as reported by Ramel (2010) and Heumou et al. (2015). According to Nayana et al. (2018), Tuta absoluta is a recently invaded pest to India and causing havoc in both open field tomatoes and in protected crops. Tuta absoluta density increased with the age of crops under both polyhouse and field conditions. According to Germain et al. (2009), the principal host of Tuta absoluta is tomato in which it can develop with the costs of all the aerial parts. But the pest can also attack other Solanaceae like potato (Solanum tuberosum L.), pepino (Solanum muricatum Aiton), aubergine (Solanum melongena L.) and sweet pepper (Capsicum аппиит L.).
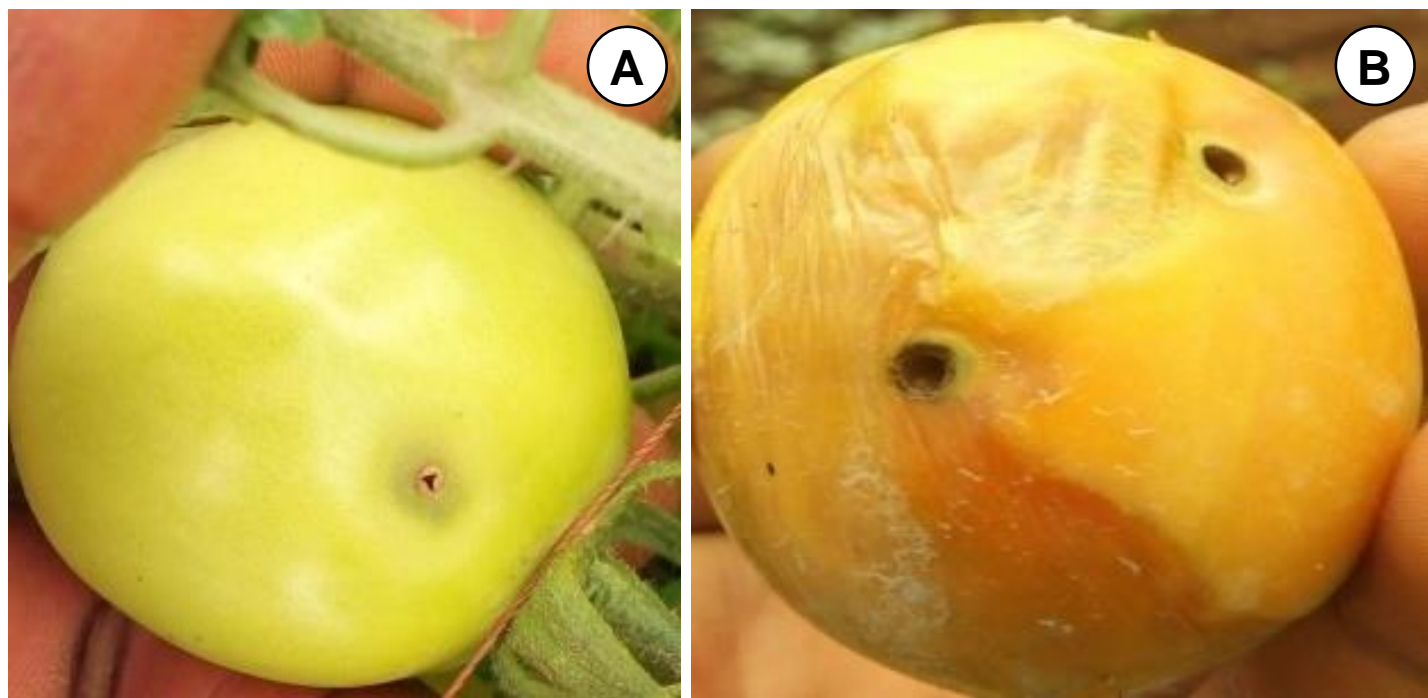

Figure 3. A, Hole of penetration of the larvae of insect pests; B, Rotting fruits (disease) with holes caused by the larvae of insect pests.

Three non-identified Hymenopteran parasitoid species were captured during this work. A total of 17 individuals was collected. In the localities of Mangoum 2 and Nkoudounbain 2, the three species were collected at a rate of an individual per species. In Baigom, only one species was collected and two species were collected in the other 4 localities. Excessive and frequent applications of insecticides to control pests as it is the case in our different localities directly affect the abundance of parasitoids as they are killed by these insecticides. This was proven by Yardim \& 
Edwards (1998) that the excessive use of broad-spectrum leads to the direct effect on natural enemies of tomato pests. The locality of Baigom which has the lowest number of parasitoids, can be due to the fact that large scope insecticides were used. We noticed a lower population of insect pests of tomato in this locality compared to the others. This indirectly affects the abundance of Hymenopteran parasitoids as they feed on either the eggs or larvae. So the smaller the insect pests' population the smaller the amount of food available for the parasitoids to survive. Koss et al. (2005) proven that the killing of insect host can lead to the shortage of food and push them to migrate from pesticide-treated fields.

\section{CONCLUSION AND RECOMMENDATIONS}

The abusive use and non-respect of doses of the chemical by farmers of tomato at Foumbot is a very serious problem for the consumers' health, for the farmers themselves, for the environment and therefore for a durable management of resources. This situation on all concerned starting for the manufacturer of the chemical products through the distributors and the users that are farmers. Are we sure that the conditions for conservation are respected by all the distributors of these chemical products? Do farmers have the required training to understand and analyse the dangers due to the non-respect of doses and frequencies of application? Do the decentralised local communities sensibilize sufficiently farmers of their localities? Do the public power through the ministries concerned do their work enough to council the vulgarisators aside the farmers? After everything, an observation is made in the locality of Foumbot and can be verified in many other basins of production, not only of tomato, but also vegetables of great consumption.

The success of a chemical fight is through the mastering of the use of the spraying material, the respect of the preparation method of the chemical products used, the doses and how frequent to apply the chemicals. The repetitive use of the same insecticide is not always recommended, it is good to vary, but using chemical products of the same family.

Other ways are to be explored in order to find a solution that will be the softest and the most respectful to the environment. The fight making use of botany should not be left out. The use of chemical pesticides and bio pesticides alternately should also be tested. The variation of the types of plants from season to another avoiding plants of the same family disturb the existence of insect pest and reduces their density.

Family exploitations are not to be neglected in rural economy. Whole families survive due to revenue from these exploitations. We believe that a great work in capacity building in the domain of management and the use of pesticides must be done for farmers groups and rural world. To be efficient and long lasting, this work needs true collaboration between all those concerned: producers of the chemical products, users, and decentralised locals communities, advertisers, researchers, lecturer-researchers in agricultural domain and the Non-Governmental Organisations (NGO).

\section{ACKNOWLEDGEMENTS}

We are grateful to the Foumbot farmers for allowing us to work in their farms and giving us all the information we needed.

\section{REFERENCES}

Daly V.D., Doyen J.T. \& Purcell A.H. (1998). Introduction to insect biology and diversity. Oxford University Press, Oxford, 680 p. Delvare G. \& Aberlenc H-P. (1989). Insects of tropical Africa and America - Keys for the recognition of the families. Prifas, Monpellier Cedex 1, France, 302 p.

Djiéto-Lordon C. \& Aléné C.D. (2002). Inventory of the insect pests and auxiliary of the cultures in the market-gardening in the area of Yaounde. Report-Cirad, Yaoundé, $35 \mathrm{p}$.

Djiéto-Lordon C., Heumou C.R., Elono A.P.S., Aléné C.D., Ngueng A.C. \& Ngassam P. (2014). Assessment of pest insects of Capsicum annuum L. 1753 (Solanaceae) in cultivation cycle in Yaoundé. International Journal of Biological and Chemical Sciences, 8(1): 621-632.

Edwards-Jones G. (2008). Do benefits accrue to "pest control" or "pesticides"? A comment on Cooper and Dobson. Crop Protection, 27(6): $965-967$

Fontem D.A., Gumedzoe M.Y.D. \& Nono-Womdim R. (1999). Biological constraints in tomato production in the western highlands of Cameroon. Tropicultural, 16-17(3):89-92.

Germain J-F., Lacordaire A-I., Cocquempot C., Ramel J-M. \& Oudard E. (2009). A new pest of tomato in France: Tuta absoluta. PHM-Revue Horticole, 512: 37-41.

Heumou C.R., Djiéto-Lordon C., Aléné C.D. \& Elono A.P.S. (2015). Diversity and agronomic status of tomato and pepper fruit pests in two agro-ecological zones of Southern Cameroon: Western Highland and the Southern Plateau of Cameroon. African Journal of Agricultural Research, 10(11): 1224-1232.

Kengne F. \& De Jong A. (2002). Rural producers in the crisis in Cameroun: Centre Province. Le Harmattan, Paris, 164 p. 
Koss A.M., Jensen A.S., Schreiber A., Pike K.S. \& Snyder W.E. (2005). Comparison of predator and pest communities in Washington potato fields treated with broad spectrum, selective, or organic insecticides. Journal of Environmental Entomology, 34: 84-95.

Markham P.G., Bedford L.S. \& Pinner (1994). The transmission of Gemini viruses by Bemisia tabaci. Paper presented in part at the symposium 'Management of Bemisia tabaci organized by M. Cahill on behalf of the SCI Pesticide Group and held at the SCI, 14/15 Belgrave Square, London SWIX 8PS, UK on 25 January 1994.

Mokam D.G., Djiéto-Lordon C. \& Bilong C.F. (2014). Patterns of Species Richness and Diversity of insects Associated with Cucurbit Fruits in the Southern part of Cameroon. Journal of Insect Science, 14(248): 1-9.

Nayana B.P., Shashank P.R. \& Kalleshwaraswamy C.M. (2018). Seasonal incidence of invasive tomato leaf miner, Tuta absoluta (Meyrick) (Lepidoptera: Gelechiidae) on tomato in Karnataka, India. Journal of Entomology and Zoology Studies, 6(1): $400-405$.

Novotny V. \& Basset Y. (2005). Host specificity of insect herbivores in tropical forests. Proceedings of the Royal Society B: Biological Sciences, 272: 1083-1090.

Ramel (2010). Tuta absoluta Meyrck (1917) Element of recognition. INPV Montpellier. Station d'entomologie, 13 p.

Shankara N., Van L., De Jeud J., De Goffau M., Van D.B. \& Florijin A. (2005). Culture of tomato: production, transformation and marketing. $5^{\text {th }}$ Ed. Foundation Agromisa et CTA, Wageningen.

Urbaneja A., González-Cabrera J., Arnó J. \& Gabarra R. (2007). Prospects for the biological control of Tuta absoluta in tomatoes of the Mediterranean basin. Pest Management Science, 68: 1215-1222.

White I.M. \& Elson-Harris M.M. (1994). Fruit flies of economic significance: Their identification and Bionomics. CAB International in association with ACIAR (The Australian Centre for International Agricultural Research), $601 \mathrm{p}$.

Yardim E.N. \& Edwards C.A. (1998). The influence of chemical management of pests, diseases and weeds on pest and predatory arthropods associated with tomatoes. Journal of Agriculture, Ecosystems and Environment, 70: 31-48. 